\title{
МИЛЕНА СТЕФАНОВИЋ
}

Универзитет уметности у Београду, Факултет драмских уметности, Београд

DOI 10.5937/kultura1653064S

УДК 7.097(73)"20"

$316.7(73) " 20 "$

17

оригиналан научни рад

\section{ПОПУЛАРНА}

KУЛТУРА ИЕТИКА

\section{СТУДИЈА СЛУЧАЈА ТЕЛЕВИЗИЈСКИХ СЕРИЈА ДОУШНИЦИ И ТРЕМЕ}

Сажетак: Захваљујући својој форми и каналима дистрибуиије, популарна култура има могућност да представи компликована и етички релевантна питаға демографски и географски широком кругу публике. Када се у популарној култури појави аутор као што је Дејвид Сајмон, и кроз уметнички изазован поступак постави суштинска питања о неједнакости, слободи и друштвеној правди, али и о колективној моралној одговорности институција, увиђамо да юегова одбрана обесправљених отвара различита питања. Кроз причање прича о савременом америчком друштву, Сајмон тврди постојање колективне одговорности институиија. На студији случаја двеју телевизијских серија, Доушници и Треме, указујемо на ставове аутора који кроз фикиију сликају (не)моралност и (не)одговорност институција, појединаца, политике.

Кључне речи: популарна култура, тв серија, морал, неједнакост, институиије

$У_{в о д}$

У савременом свету глобалних комуникација, медијски садржаји свих врста и облика играју кључну улогу у процесу ширења сазнања о свету у коме живимо. Телевизијске серије као мали део тих садржаја, захваљујући свеприсутном каналу дистрибуције, имају глобалну доступност и покривеност. 
Оне представљају део популарне културе, и последњих година по многима узимају примат над филмском индустријом која се по многима успавала у превазиђеном бизнис моделу. ${ }^{1}$ ТВ серије се налазе у, Бурдијеовски схваћеном, субпољу масовне културне продукције у коме се наглашава комерцијални аспект, насупрот суб-поља ограничене културне продукције у коме се налази елитна уметност ниских комерцијалних могућности и високих уметничких квалитета. Ова Бурдијеова подела не значи да ће нужно свака пракса из субпоља масовне културне продукције имати низак уметнички квалитет и високе комерцијалне потенцијале, већ ће њихови атрибути зависити од низа фактора.

Феномен развоја телевизијских серија последњих година је честа тема и у стручној и у популарној литератури. Доминик Моиси који истражује геополитику телевизијских серија указује да су сценаристи и ауторски тимови постали најбољи аналитичари савременог света. Анализирајући телевизијске серије које су смештене у политичке миљее, као што су „Кула од карата”, „Домовина”, „Западно крило”, „Премијерка”, Моиси тврди да оне интерпретирају на мање или више успешан начин геополитику савременог света. ${ }^{2}$

По филозофу Карлу Поперу, сваки човек има неку своју филозофију, знао он то или не, а утицај те (не)свесне филозофије на наше мишљење и деловање је разорно. Стога Попер сматра да своје филозофије морамо критички истражити, и уколико се сложимо са Моисијем, можемо рећи да популарна култура садржи интерпретацију геополитике на коју у одређеној мери утичу ставови и личне филозофије аутора тих садржаја. Циљ овог истраживања је да преиспита етичке принципе на којима аутор Дејвид Сајмон, заједно са својим ауторским тимовима, заснива приче, и преиспитује релевантна питања и отвара болне тачке савременог друштва кроз формат тв серија.

Свакако треба приметити да процес причања прича кроз фикцију, неминовно суочава и ауторе и публику са пуно етичких питања, од грађења појединачних карактера до свеукупног моралног става који аутори исказују кроз причу. Међу истраживачима, етика репрезентације све више бива замењена етиком наратива као форме имагинације и фикције, стога у тексту говоримо о етици наратива јер студија случаја коју ћемо користити, се заснива на причању прича. Асман

1 Green E., The Atlantic, Why TV is pummeling the movie industry, 27 September, 2013, приступљено 1 октобар 2016, http://www.theatlantic.com/business/archive/2013/09/why-tv-is-pummeling-the-movie-industry/280086/

2 Moisi D., (2016) Geopolitika televizijskih serija, Beograd: Clio. 
сматра да је релевантност наратива за културну меморију веома битна, а културну меморију дефинише као меморију у којој је изабрани садржај из прошлости кодификован и стандардизован кроз споменике, музеје, годишњице и у њеном стварању улогу играју и појединци и организације. ${ }^{3}$ Стога морални ставови који се изражавају кроз уметничко стваралаштво без обзира на форму, умногоме утичу на то какву културну меморију стварамо и остављамо на увид и за даља истраживања будућим генерацијама.

С друге стране, етичност или моралност поступака има различито значење у различитим религијама, културама, историјским раздобљима, пошто је интерпретирана од стране владара, политичара, организација, влада на другачије начине. Већина филозофских речника ${ }^{4}$ разликује појам етике од појма морала, и док етику дефинише као филозофску дисциплину која се бави питањима шта је морално а шта није морално, морал дефинише као разлику између тога шта је исправно или добро а шта неисправно или лоше понашање или поступак.

\section{Античко поимање етике и савремена етика}

Главна подела етичких теорија је на деонтолошке и утилитарне. Ова прва група етичност посматра као универзални и обавезујући принцип (и њено порекло се везује за античку Грчку), а утилитаризам за основни принцип има идеју да се етичност поступака мери само у односу на њихове ефекте тј последице које изазову. По деонтолошком схватању, лаж је лоша сама по себи, и није дозвољена ни под каквим околностима, док утилитаризам процењује позитивне последице лажи и у складу са том проценом, (не)дозвољава лаж. Са филозофског становишта, принципи ових двају теорија су некомпатибилни, али појединац је у свакодневном животу углавном приморан да комбинује и да балансира између ова два принципа.

Даље, утилитаризам као најпознатија и вероватно најприсутнија етичка теорија данас, раздваја „исправност” карактера индивидуе од „исправности” његових или њених поступака. По утилитаризму, могуће је да неморална особа уради моралну ствар, као и да је морално исправна особа способна за морално неоправдан поступак. Утилитаристи моралност мере и оправдавају у релацији са количином добробити коју неки поступци имају за човечанство. Дакле,

3 Asman, J. (2001) Kultura pamćenja, Beograd: Prosveta.

4 Stanford Encyclopedia of Philosophy pristupljeno 28 septembra http://plato. stanford.edu/entries/morality-definition/ 
последице и резултати поступака, али и политика и закона су једино мерило да ли су ти поступци, закони и политике етички исправни. По утилитаристима увек треба бирати опцију која максимализује корист за највећи број јединки, и опцију која производи највећу количину добра. Насупрот томе, класична, античка теорија или теорија врлине из које се касније развила деонтолошка доктрина, претпоставља да особа од врлине увек поступа морално исправно.

Ипак, поставља се питање шта значи „добро”. По Џеремију Бентаму (Jeremy Bentam), једном од најпознатијих утилитариста, добро представља задовољство, или срећу. Ипак, многи критичари су одбацили овакво његово схватање као лимитирајуће јер постоји много доброг што не претпоставља нужно задовољство и срећу. Стога су увели појам добробити (wellbeing) као онога што описује добро по себи. Овај став изазива питање о чијој добробити се говори, и ту се јавља подела на сопствену добробит, групну (породица, пријатељи), добробит свих (свеукупна). Иако нема простора за детаљније представљање свих утилитаристички праваца, указаћемо на још једну дистинкцију у оквиру ове теорије.

Од педесетих година прошлог века, појавила се подела на утилитаризам поступка и утилитаризам правила. Утилитаризам поступка наглашава контекст и специфичност сваке ситуације у којој се одлучује о исправности неке одлуке или поступка, док утилитаризам правила указује на неопходност посебних правила у случајевима када говоримо о злочинима, лажима, кажњавањима, итд. У сваком случају, оба типа утилитаризма тврде да исправност поступка одређује однос између онога што радимо и утицаја моралности нашег поступка на ниво или количину добробити других. ${ }^{5}$

Морална одговорност и морално поступање су најчешће поимани и дискутовани у контексту односа појединца спрам различитих група - пријатеља, породице, колега. С друге стране, колективни поступци који као последицу имају патњу, несрећу, смрт и уништење живог света на планети, све су чешће у фокусу дебате о колективној моралној одговорности спрам одређених поступака. Док у области индивидуалне моралне одговорности донекле постоји слагање о основним принципима моралног поступања, у сфери колективне одговорности заједничког става или основног принципа спрам колективне моралне одговорности нема. Питање колективне моралне одговорности сукобљава два става, став да се само појединци могу сматрати морално одговорним и става да се

5 Nathanson S., Internet Encyclopedia of Philosophy, pristupljeno 2. oktobra 2016. http://www.iep.utm.edu/util-a-r/ 
групе (било да се ради о корпорацијама, организацијама, заједницама, нацијама) могу сматрати морално одговорнима за своје поступке или последице својих поступака. Истраживач на пољу политичке теорије, Лук (Lukes Steven) ${ }^{6}$ указује на везу између одговорности и моћи, тврдећи да се од организација очекује баш као и од индивидуа морално поступање уколико њихов рад и последице имају везе са установљеним и прихваћеним друштвеним моралним нормама и стандардима. Рисер (Risser David) сматра да и приватне и јавне организације, као људска креација, немају морална права и да кроз законски оквир и законска права, која имају, дају довољан оквир за заштиту људских интереса. ${ }^{7}$ Овај аутор и тврди да је ниво личне одговорности у директној размери са нивоом утицаја коју појединац има када се ради о практичном доношењу одлука.

\section{Популарна култура и тв серије}

Дејвид Сајмон, продуцент и писац, је по многима феномен сам по себи. Кроз две телевизијске серије, које ће бити предмет анализе овог текста, Доушници и Треме, Сајмон је покушао да покаже постојање колективне одговорности савременог америчког друштва. Избором тема и порука које медијски писмен читалац тј. гледалац уочава, аутори покушавају да покажу како популарна култура може бити релевантан инструмент преиспитивања савременог морала институција и политике у савременом свету. Ипак, остаје отворено питање на које ћемо покушати да одговоримо да ли и у којој мери ова форма јесте била успешна у дистрибуцији не превише лаких и (не)популарних ставова спрам америчког мита о слободи, и друштвеној једнакости.

Популарна култура није кохерентан појам и подложна је мењању, тако је током шездесетих година двадесетог века када је настајала, обликовала своју пасивну и активну улогу. ${ }^{8}$ Јанковић указује да се пасивна улога огледа у тенденцији популарне културе да буде огледало ствари какве јесу и какве би требало да буду, додајући гламур у извесној мери у домену индустрије забаве, док се активна улога ослања на њен потенцијал друштвеног деловања и утицаја. Популарна култура може да предводи велике промене, „као и смене социјалних ставова према рату и разарању, породици, религији

6 Luke, S. (1974) Power: A Radical View, London: Macmillan press.

7 Riser, D. (1996) The social dimension of moral responisibility: taking organizations seriously, Journal of Social Philospohy, Vol 27, 1, p. 189-207.

8 Janković, A. (2011) Dug i krivudav put: Bitlsi kao kulturni artefakt, Beograd: Red books. str. 7 . 
и осталим важним питањима од шездесетих наовамо". 9 Политички и морални ставови који су врло јасно изречени у серији Доушници и Треме, указују да се ради о активном типу популарне културе.

Обе серије су продукција кабловског канала ХБО, а као главне актере имају не особе већ два америчка града, Балтимор и Њу Орлеанс. Кроз животне драме мноштва јунака, серије дају ширу слику урбане Америке са почетка овог века. Серија Доушници се приказивала на америчком (и европском) тржишту од 2002. до 2008. године, и имала је шездесет епизода распоређених у 5 сезона. Серија Треме, приказивала се од 2010. до 2013. и имала је тридесет шест епизода и 4 сезоне.

Дакле, средиште приче јесте непрестана борба појединца са институцијама система, било да се налази у оквиру или изван њих. Сам избор градова битно одређује поруке аутора. Наиме, већина америчких серија за место дешавања, бира метрополе, као што су Лос Анђелес, Њујорк, Бостон, Вашингтон, у последње време Сијетл (Увод у анатомију, Убиство). С друге стране, Сајмон смешта причу у два средње велика америчка града: Балтимор и Њу Орлеанс. Балтимор (држава Мериленд) налази се на источној обали и велика је лука. Некада велики индустријски центар, последњих десет година бори се са падом популације и сиромаштвом. Више од половине становништва Балтимора чине афро-американци (63\%), већина је незапослена, $80 \%$ деце не заврши основну школу, а број насилних злочина је изнад америчког просека. ${ }^{10} \mathrm{C}$ друге стране, Треме је кварт у Њу Орлеансу, (држава Луизијана) у граду који такође има већинско афроамеричко становништво. Серија прати догађаје после 2005. године када је лука на јужном крају Сједињених држава била погођена ураганом Катрина, једним од најсмртоноснијих у америчкој историји, у коме је погинуло више од хиљаду становника. Иначе, Треме је музичко срце града, и датира из 18. века, када је афро-американцима било дозвољено да на тргу Конго у овом кварту, певају и плешу.

Иако Сајмона често називају марксистом, јер су тема његових серија маргинализоване групе, он у једном интервјуу каже: „Нисам марксиста. Често ме грешком тако називају. Људска бића у овој земљи вреде све мање и мање. Имамо Америку какву смо заслужили јер смо допустили да се десе

9 Исто, стр. 7.

$10 \mathrm{https} / /$ suburbanstats.org/population/maryland/how-many-people-live-inbaltimore, 6. oktobar2016. 


\section{МИЛЕНА СТЕФАНОВИЋ}

неке ствари."11 У овој изјави увиђа се Сајмонов лични став о постојању колективне одговорности, који он, причајући причу о делу урбане популације која је делимично заборављена и маргинализована, указује на степен групне одговорности коју има америчко друштво.

По Фиску, поп је производ англо америчког либерализма који се ствара у условима субординације, и стога настаје као реакција на силе доминације а никада као њихов део. ${ }^{12}$ Можемо рећи да поменуте ТВ серије представљају поп производ који регује на силе доминације, на силе политичког и друштвеног естаблишмента. Као такве, представљају инструмент друштвене и моралне критике друштва и доносиоца одлука који држе моћ у својим рукама.

\section{Доушниции}

Прича о Балтимору подељена је кроз 5 сезона и смештена је у контекст илегалне трговине дрогом, бродоградилишта на коме је почивала економија града а које пропада, система јавног школства, јавне администрације и локалних штампаних медија. Шездесет минутне епизоде показују системске грешке институционалног модела савремених Сједињених америчких држава, и неправедан положај појединаца унутар система.

Први очигледан став који се провлачи кроз све приче је да је систем институција постављен тако да ограничава могућности урбане популације која је сиромашна, и да њихови ставови и веровања су потпуно одређени тим институционалним контекстом у коме су рођени и у коме се (не)развијају. Чада и Вилсон (Chaddha and Wilson) у критичкој расправи о серији Доушници, наводе да $67 \%$ американаца сматра да су афро-американци сами криви за економски положај у коме се налазе, док само 18\% сматра да је то последица дискриминације. ${ }^{13}$ Даље наводе да 70\% белаца, $69 \%$ хиспано американаца, и 52\% афро-американаца сматра да су афроамериканци који не успевају сами криви за свој положај. У складу са овим подацима, сматрају да серија Доушници не узима у обзир ове податке, већ приказује како су појединачне одлуке припадника урбане сиромашне популације увек одређене друштвеним околностима.

11 Sajmon D., Viceland, april 2014, pristupljeno 3. oktobar 2016. http://www. viceland.com/int/v16n12/htdocs/david-simon-280.php?page $=2$

12 Fisk, Dž. (2004) Popularna kultura, Beograd: Clio, str. 54

13 Chadda and Wilson, Washington post, Why we are teaching Wire at Harvard, 12 sept 2010, pristupljeno 28 septembar 2016 https://www.hks.harvard.edu/ news-events/news/news-archive/teaching-the-wire-at-harvard 
Захваљујући уметничкој слободи, аутори серије имају могућност да нагласе аспекте урбаног сиромаштва и неједнакости на начин и у мери која одговара њиховом уметничком поступку и политичком ставу. Дакле, они указују да већи део одговорности почива на америчком институционалном систему а не на појединцу, иако горе наведено истраживање тврди да већина американаца, из било које расне групе да долазе, сматра да се ипак ради о индивидуалној одговорности а не колективној тј институционалној.

У прве две сезоне серије, пратимо причу трговине наркотицима у тзв „гето” насељима, за борбу против које је формирана посебна јединица полиције. Иако са једне стране завршавају криминалне послове у оквиру система у коме се налазе и за своје криминалне шефове, ликови као Валас (Wallace) и Омар (Omar) у активностима које нису директно везане за „посао” понашају се морално и друштвено одговорно. Валас, тинејџер који док се доказује гангстерима за које ради, истовремено чува групу млађе деце (неки су му браћа, а неки рођаци без породице) у једном од станова у комшилуку, у згради и насељу у коме живе само афро-американци и у којој су пљачке и криминал сваке врсте, дневна појава, а полиција ретко залази у те крајеве. Валас деци обезбеђује храну, води их у школу, и помаже им око домаћих задатака, понашајући се као старатељ. Све време се преиспитује да ли је спреман за посао у гангу, и на крају бива убијен од стране свог претпостављеног који сумња у његову лојалност. С друге стране, имамо лик Омара, који је нека врста модерног Дон Кихота, који није део главне криминалне групе чије су вође Авон Барксдејл (Avon Barksdale) и Стрингер Бел (Stringer Bell). Омар отима дрогу од ганга и пљачка тајна складишта, водећи се личним кодом да у његовим акцијама не смеју да страдају недужни и случајни грађани, који нису повезани са њиховим „послом”. Ова дихотомија која осликава с једне стране улицу (посао) а са друге стране неки друштвени живот и приватно понашање (укључујући и унутрашња превирања, преиспитивања и тензије) карактеришу јунаке који живе кроз два морална принципа, добра и зла. Мотиви за криминалне радње које свакодневно чине су углавном последица циљева криминалног ганга у коме раде и од кога директно зависи њихова егзистенција али и егзистенција њихових породица. Ови мотиви за насиље и криминал су различити од психолошких и емотивних извора насиља. Креирајући овакве двојне карактере, аутори се приклањају моралном релативизму, јер гледалац може да схвати криминал који је део свакодневног посла тих појединаца као оправдан јер има „вишу” сврху, а то је храна и буквално преживљавање Валасове млађе браће на пример. Дакле, у 
својим „приватним” животима, ликови попут Валаса, поступају морално чувајући млађе и бринући да ли ће изаћи на пут без криминала. Омар такође представља пример моралне дихотомије, који криминал сматра нужним злом везаним за тзв. посао, док друштвени живот, обавезе и неки спољни свет, покушава да изузме.

Иако аутори не описују генезу криминалне групе као ни појединачне мотиве и приче свих припадника нарко клана, видимо да и међу њима има оних којима мотив за злочин нису увек пословни циљеви групе. У ствари, аутори врше поделу на „добре” и „лоше” криминалце, тако да гледалац навија за условно речено добре криминалце јер њихови поступци су повезани са неким „вишим” циљем, дакле видимо на делу утилитаризам поступка.

Поједини аутори и Сајмонови критичари, сматрају да серија Доушници подржава стереотип о афро-американцима као лењим и неморалним криминалцима. ${ }^{14}$ Чињеница је да популарна култура има велике заслуге за стереотипизацију. Ипак, чини се да балансираним приказом карактера из различитих слојева популације, аутори Жице не упадају у замку стереотипа. Иако то није фокус овог истраживања, женски карактери у серији Треме су, на пример, врло нетипични и антипод стереотипу.

Серија Доушнищи у другој сезони се фокусира на сиромаштво белаца који се због све веће економске кризе, аутоматизације индустрије, општег смањења обима послова у Балтиморској луци, окрећу криминалу: од кријумчарења људи до трговине дрогом. За разлику од припадника нарко клана који се од самог рођења у савременим гетоима сусрећу са криминалом, изненадна економска неизвесност тера вође синдиката лучких радника на улазак у сумњиве послове са правим криминалцима. Соботка, лидер синдиката, очекујући да ће успети да креира посао за лучке раднике кроз лобирање и уцену градских власти, бира криминал као средство за постизање вишег циља. У овој причи о Балтиморским доковима видимо да се и радничка класа осећа изневереном од стране институција и система, јер не успева да се преквалификује у систему у коме се смањује потреба за њиховим радом. Ова прича о лучким радницима јесте и прича о аутомобилској индустрији у Детроиту, и свим великим индустријским секторима, у којима због све веће аутоматизације и развоја технологије, радници оператери су остали

14 Bowden M., The Atlantic, The angriest man on television, januar/februar 2008, pristupljeno 9 oktobar 2016.http://www.theatlantic.com/magazine/archive/2008/01/the-angriest-man-in-television/306581/ 
МИЛЕНА СТЕФАНОВИЋ

без егзистенције, а институције нису успеле да предвиде и креирају неке нове послове за њих.

Насупрот криминалној групи која живи и ради у афро-америчком делу града, је мала група полицајаца, која је у првој сезони окупљена од стране градске администрације и директора полиције, са задатком да разоткрије нарко ганг који користећи нове методе комуникације успева да води посао а да не буду разоткривени. ${ }^{15}$ Двојица главних полицајаца, Џими Мекналти и Лестер Фримон су одлучно на страни добра, иако приватан живот Мекналтија, не указује на превише одговорно понашање (алкохол, жене, занемаривање породице). Професионални труд и залагање овог полицијског тима није увек препознат. Напротив, у појединим сценама види се да њихове несвакидашње методе сметају одређеним полицијским структурама који теже одржавању континуитета, без таласања, док се баве својим каријерама и напредовањем у систему. Полицијска изузетност у раду није третирана као врлина, већ углавном доводи до деградације положаја, што се и види на крају друге сезоне.

Једна од паралелних прича која није од суштинске важности за ток догађаја, представља причу о малом друштвеном експерименту у оквирима заједнице у којој живе афро-американци. Дакле, користећи утилитаризам, аутори експериментишу са подршком мањем злу, које иако нелегално производи бар привремени мир. Наиме, начелник полиције, без знања својих претпостављених, ,легализује” продају дроге у Западном Балтимору, јер сматра да је илузорна без обзира на труд, борба против дроге. Операционализацијом ове одлуке начелника полиције драстично опада број насилних злочина, криминална статистика као важан показатељ успеха политичара се после дугог низа година поправља, а локална полиција почиње да упознаје и помаже становницима насеља. С друге стране, аутори не минимализују негативне аспекте оваквог решења, јер прича показује да квартови где се дрога слободно продаје постају попришта свеприсутног уживања наркотика која обичне становнике приморава на исељавање, док видимо да се здравствено стање великог броја зависника погоршава. Када прича доспе у локалне новине, начелник бива смењен, улични рат и обрачуни постају свакодневни. Политички ово је прихватљиво јер се структуре поново „формално” боре против трговине наркотицима. Прича показује да морални релативизам влада и са стране закона, па критичари најчешће замерају Сајмону недостатак равнотеже у приказу, сматрајући да не приказује карактере

15 Отуда потиче и назив серије Доушниции. 
који нису подложни релативизму, већ су обични, пристојни и храбри људи, који се на свој начин боре против зла, одлазећи у крајност и претеривање. ${ }^{16}$

\section{треме}

Чињеница да је кабловски канал ХБО одлучио да продуцира серију чија је тема град, који после природне катастрофе покушава да превазиђе трауму, указује на одговорност и потребу да шири круг публике можда по први пут види какве су биле размере овог догађаја. Сем тога, Треме је и прилика да се публика упозна са институционално неадекватним одговором и да отвори платформу за дискусију о будућности остатка заједнице која је преживела трауму. Иако се не ради о документарном филму, већ о фикцији, причањем приче о природној катастрофи из различитих перспектива, стиче се утисак о целини. Главна личност ове серије је сам град, који покушава да се опорави после урагана Катрина који је погодио Њу Орлеанс 29 августа 2005. Десет година после урагана, становници своја сећања почињу реченицом: „Катрина је била лака. Последице су биле тешке. Али ово схватамо као нову шансу да се крене како треба из почетка."17

У превазилажењу колективе трауме и ре-креацији идентитета и сећања заједнице после велике трауме, битну улогу може да одигра управо причање прича. ${ }^{18}$ У фикцији су трауматични догађаји приказани, дато им је значење и интерпретација. Стога, иако је важно какав је био првобитан доживљај трауматичног догађаја, релевантно је за друштвену историју у какав се културни оквир ставља. У популарној култури, приче о траумама користе се да се подрже или критикују одређени поступци, и политичке одлуке. Аутори серије Треме користе приче да укажу на постојање одговорности локалних политичара и дела институција које нису биле спремне за одговорну и брзу реакцију када се катастрофа десила. Потом, указују и на контроверзност одлука и понашања јавних власти после урагана, када је град покушао да се врати свакодневном животу. „Професионална етика при примени закона је одсутна" кратак је опис понашања локалних снага реда у Њу Орлеансу после урагана Катрина. ${ }^{19}$ У другој

16 Bowden, M. The Atlantic, The angriest man on television, januar/februar 2008, 9 oktobar 2016.http://www.theatlantic.com/magazine/archive/2008/01/the-angriest-man-in-television/306581/

17 http://www.history.com/topics/hurricane-katrina

18 Alexander, J., Eyerman, R., Giesen, B., Smelser, N. and Sztompka, P. (2004) Cultural trauma and collective identity, University of California Press.

19 Chilton, M. Guardian, Tremé: Best thing on TV and so few are watching, 9. april 2015., 9 oktobar 2016. http://www.telegraph.co.uk/culture/tvandra- 
епизоди прве сезоне, која се дешава четрнаест месеци после урагана, један од карактера, млада девојка Софија поставља на интернет видео у коме описује своје виђење ситуације у граду, и каже да Национална гарда маршира у групама и легитимише пролазнике („као да смо у Фалуџи”) док староседеоци одбијају да напусте град, трагајући по рушевинама. Аутори указују да сем што је савезна администрација послала Националну гарду да заведе ред, није урадила довољно на обнови града. Такође, индиректно упоређују реакцију савезне државе после терористичког напада у Њујорку у односу на реакцију у Њу Орлеансу, сматрајући је неадекватном у случају Њу Орлеанса.

Моралног релативизма у карактерима нема. Сви становници Њу Орлеанса који остају у разрушеном граду јединствени су у ставу да морају да пробају да преживе и сачувају локалну традицију и културу: и неодговорни тромбониста, и ди џеј, и власница локалног бара, и виолинисткиња, и професор књижевности, власница ресторана, адвокат, итд.

\section{Закључак}

Пјер Верњо (Pierre Vergniaud), адвокат из Бордоа, говорник Жирондинског клуба, у својој беседи о Америци и слободи 1791. године, подсећа да је Америка рођена у муци која вековима не може бити заборављена. ${ }^{20}$ За цивилизацију која се отуђила од своје домовине тврди да не постоје основни закони ни политичка убеђења јер таквих осећања без домовине нема, указујући на дубок проблем идентитета америчког народа, насталог на коренима индијанаца и афро-американца који су били поробљивани и протеривани са своје земље. Више од два века касније, положај дела америчке урбане популације, и даље је извор и инспирација многим уметницима и мислиоцима.

Непопуларне теме као што је живот у савременом америчком гету и град после природне катастрофе су донеле Дејвиду Сајмону, статус борца за правду. Ипак, гледаност ових серија није била превелика. Ако упоредимо гледаност са другим серијама, видимо да је, на пример, премијерне епизоде серије Хитна помоћ у Сједињеним државама гледало и до тридесет три милиона гледалаца, док сајт Холивуд репортер преноси да је прву сезону серије Треме у просеку гледало милион и четири стотине гледалаца. С друге стране, двд издања серије Доушнищи на сајту Амазона годинама су

dio/10064886/Treme-Best-thing-on-TV-and-so-few-are-watching.html

20 Верњо, П. (2004) Одговор Бриосоу о америчкој слободи, према Браниславу Нушићу, Реторика, Ниш: Зоограф, стр. 34. 
међу најпродаванијим издањима. Серије су заобишле и награде као што су Златни Глобус и Еми, стога се поставља питање о томе колико је заиста био широк канал дистрибуције критичких прича из ове две серије. Имајући у виду да је успешнија била продаја двд издања у односу на кабловску гледаност, може се рећи да је серија ипак више погодила део публике која се слаже са ауторима о постојању колективне одговорности и у критици савременог америчког друштва.

У сваком случају, аутори су пажљивим грађењем ситуација и карактера, исказали етички и политички став да економски и друштвени положај у коме се актери драме налазе, без обзира да ли се ради о афро-американцима или белцима, није нужно последица „лоших” карактера или наклоности коју имају ка криминалу и злочину већ је узрокована, у великом броју случајева, институционалним оквиром из кога потичу и у коме живе. Њихова порука је да, пре свега, образовни систем није развио механизме просвећивања друштвено изолованих, мањинских група, који и када се нађу у животном изазову, не успевају да сагледају ширу слику и нађу пут који их неће одвести у контроверзне или криминалне послове. Указујући на колективну институционалну одговорност, аутори на известан начин оптужују све оне који стварају и чине те институције (од политичке елите до Вол Стрита), јер управо те интересне групе не успевају да направе систем и јавност која ће бити способна да критички мисли.

Морални релативисти би, гледајући Сајмонове серије, приметили да су сва друштва несавршена, и да неједнакост свуда постоји. Иако је ово истина, уметност има обавезу да критички промишља друштвене феномене и да без обзира о којој врсти стваралаштва се ради, не престаје да указује на појединачну и колективну одговорност. Популарна култура стога може имати битну улогу, и иако је до сада пуно урадила на плану феминизма (на пример, кроз серије Секс и град), до серија Доушници и Треме, није било покушаја да се укаже на колективну одговорност институција и друштва, које док суштински не промени јавне политике спрам јавног школства, расне и класне неједнакости, и борбе против дроге, градови попут Балтимора и Њу Орлеанса, биће подељени или запостављени.

И да закључимо цитирајући Борислава Пекића: „Треба се придружити људима који бране неко право, неки виши вид људске егзистенције, чак и ако се човек са њима у потпуности не слаже. То са политиком нема никакве везе. То је чисто морално питање."21

21 http://www.borislavpekic.com/2007/09/ideje-o-moralu.html 
МИЛЕНА СТЕФАНОВИЋ

\section{ЛИТЕРАТУРА:}

Green, E. The Atlantic, Why TV is pummeling the movie industry, 27 September, 2013, приступљено 1 октобар 2016, http://www.theatlantic.com/business/archive/2013/09/why-tv-is-pummeling-the-movie-industry/280086/

Moisi, D. (2016) Geopolitika televizijskih serija, Beograd: Clio. Janković, A. (2011) Dug i krivudav put: Bitlsi kao kulturni artefakt, Beograd: Red books.

Asman, J. (2001) Kultura pamćenja, Beograd: Prosveta.

Stanford Encyclopedia of Philosophy http://plato.stanford.edu/entries/ morality-definition/

Nathanson S., Internet Encyclopedia of Philosophy, pristupljeno 2. oktobra 2016. http://www.iep.utm.edu/util-a-r/

Luke, S. (1974) Power: A Radical View, London: Macmillan press.

Riser, D. (1996) The social dimension of moral responisibility: taking organizations seriously, Journal of Social Philospohy, Vol. 27, 1.

Sajmon, D., Viceland, april 2014, pristupljeno 3 oktobar 2016. http:// www.viceland.com/int/v16n12/htdocs/david-simon-280.php?page=2

Fisk, Dž. (2004) Popularna kultura, Beograd: Clio.

Chadda and Wilson, Washington post, Why we are teaching Wire at Harvard, 12 sept 2010, pristupljeno 28 septembar $2016 \mathrm{https}: / / \mathrm{www}$. hks.harvard.edu/news-events/news/news-archive/teaching-the-wire-at-harvard

Bowden, M., The Atlantic, The angriest man on television, januar/ februar 2008, 9 oktobar 2016.http://www.theatlantic.com/magazine/ archive/2008/01/the-angriest-man-in-television/306581/

Alexander, J., Eyerman, R., Giesen, B., Smelser, N. and Sztompka, P. (2004) Cultural trauma and collective identity, University of California Press.

Chilton, M., Guardian, Tremé: Best thing on TV and so few are watching, 9. april 2015., 9 oktobar 2016. http://www.telegraph.co.uk/ culture/tvandradio/10064886/Treme-Best-thing-on-TV-and-so-feware-watching.html

Верњо, П. (2004) Одговор Бриосоу о америчкој слободи, према Бранислав Нушић, Реторика, Ниш: Зограф. 
МИЛЕНА СТЕФАНОВИЋ

Milena Stefanović

University of Arts in Belgrade, Faculty of Drama Arts, Belgrade

\title{
POPULAR CULTURE AND ETHICS - CASE STUDIES OF THE TV SHOWS THE WIRE AND TREME
}

\begin{abstract}
Thanks to a specific form of distribution, popular culture has potential to present complicated and ethically relevant issues to the widest audience. When someone like David Simon appears in the field of popular culture, and through an artistically challenging process asks essential questions regarding inequality and social justice, claiming collective moral responsibility of the public institutions, we see that this narrative opens many different issues. By telling stories about the contemporary American society and its flaws, Simon claims collective institutional responsibility. Based on an analysis of two TV shows, The Wire and Treme, we will discuss ethics of the institutions, individuals and policies.
\end{abstract}

Key words: popular culture, TV show, morality, inequality, institutions

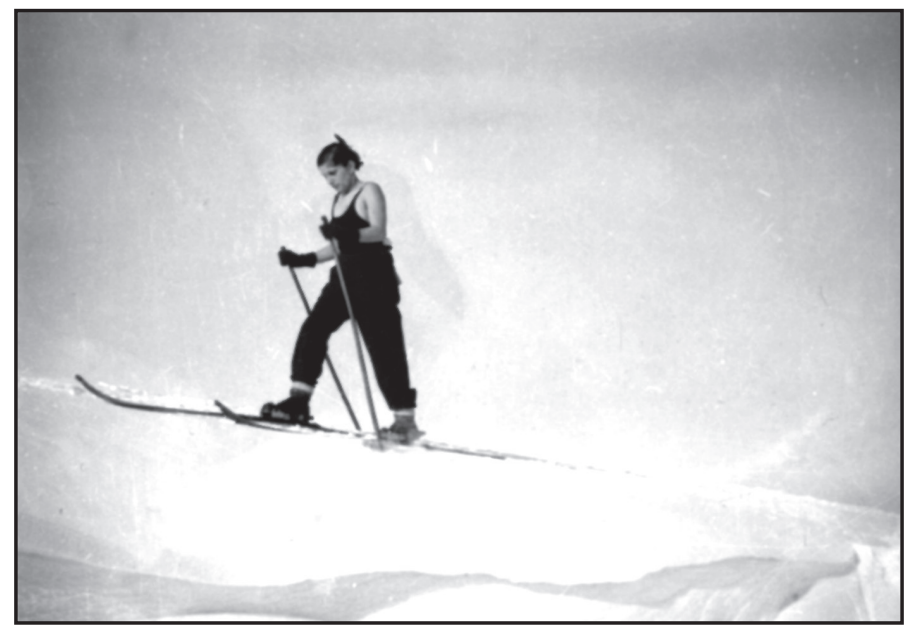

Фотографија Милоша Црњанског преузета из књиге Атлас о Црњанском, аутора Слободана Зубановића; власништво је Задужбине Милоша Црњанског у Београду 